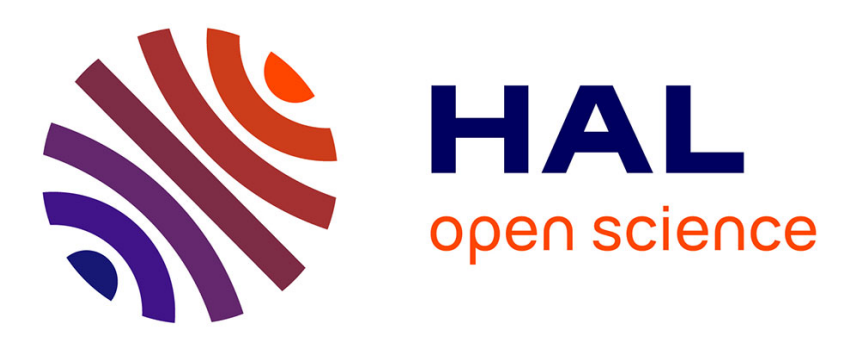

\title{
"Lineage and Virtue in Josephus: The Respective Roles of Priestly Worldview and Roman Culture"
}

Katell Berthelot

\section{To cite this version:}

Katell Berthelot. "Lineage and Virtue in Josephus: The Respective Roles of Priestly Worldview and Roman Culture". Journal of Ancient Judaism, 2020, 11 (1), pp.26-44. 10.30965/21967954-12340003 . hal-03078850

\section{HAL Id: hal-03078850 https://hal.science/hal-03078850}

Submitted on 17 Dec 2021

HAL is a multi-disciplinary open access archive for the deposit and dissemination of scientific research documents, whether they are published or not. The documents may come from teaching and research institutions in France or abroad, or from public or private research centers.
L'archive ouverte pluridisciplinaire $\mathbf{H A L}$, est destinée au dépôt et à la diffusion de documents scientifiques de niveau recherche, publiés ou non, émanant des établissements d'enseignement et de recherche français ou étrangers, des laboratoires publics ou privés. 


\title{
Lineage and Virtue in Josephus: \\ The Respective Roles of Priestly Worldview and Roman Culture
}

\author{
Katell Berthelot \\ CNRS / Aix-Marseille University*
}

\begin{abstract}
This article assesses the importance of both lineage and virtue in Josephus' notions of the Jewish nobility and the Jewish people. Furthermore, it investigates the respective roles of Josephus' priestly education and his exposition to Roman culture in his use of such concepts. I argue that while Josephus tended to identify Jewish nobility with the priesthood and thus stuck to a strictly genealogical model, he was nevertheless impacted by Roman or Greco-Roman discourses on nobility. He thus highlights his ancestors on the maternal side, in opposition to the biblical, patrilineal model. His work also reflects the common view that true nobility goes along with virtue. Yet - in contrast to Philo and Seneca — he does not embrace the philosophical discourse that radically minimizes the importance of noble birth in favor of the nobility of the soul. Moreover, because membership in the Roman nobilitas was granted both through birth into a patrician family and through election to the consulship, while membership in the Jewish priesthood was a genealogical fact and not an honor granted to those who were particularly worthy, Josephus could not adopt the Roman sociopolitical view of nobility either. His redefinition of the Jewish nobility in a Roman context therefore remains limited.

By contrast, Josephus' definition of the kinship (oikeiotess) that unites the members of the Jewish people as based either on birth/common ancestors or on choice (the choice to live under Jewish laws, implicitly characterized as virtuous) in Against Apion reflects the impact on the Judean historian of Roman citizenship grants and the pro-Roman discourses that praised this policy. As in Philo's work, Josephus' demonstration rests on the metaphorical definition of Israel as a civic body, which theoretically implies that proselytes ("new citizens") are equal to native Jews and that birth and virtue (understood as the will to live under Jewish laws) are two equally legitimate ways to become members of Israel.
\end{abstract}

Keywords

Josephus, Philo, lineage, genealogy, ancestry, nobility, virtue, conversion to Judaism, proselytes, Jewish laws, civic body, citizenship grants, Rome

\footnotetext{
* This research has been funded by the European Research Council (ERC) under the European Union's Seventh Framework Program (FP/2007-2013)/ERC Grant Agreement no. 614 424. It has been conducted within the framework of the ERC project JUDAISM AND ROME, under the auspices of the Centre national de la recherche scientifique (CNRS) and Aix-Marseille University, UMR 7297 TDMAM (Aix-en-Provence, France).
} 
In a recent study of the terms genos and ethnos in Josephus' work, Erich Gruen argues that while Josephus uses genos frequently in relation to individual lineage, especially to refer to Jewish priestly ancestry or royal ancestry, he did not view the people of Israel primarily in genealogical terms. ${ }^{1}$ According to Gruen, " $\gamma \varepsilon$ Évos in Josephus's works can certainly carry the connotation of a group united by kinship," as when "Josephus asserts that the $\gamma \varepsilon$ 'vo derives from Abraham," yet this use of the term is in fact rare. ${ }^{2}$ Josephus often employs the word to speak about a "people," without specification (the genos of the Egyptians, of the Romans, etc.). In short, in relation to Israel, genos does not necessarily carry genealogical overtones, and this is all the more true of the word ethnos, which is very often "linked to observances, rules, conventions, behaviors, or ways of life."3 Moreover, in his retelling of Balaam's prophecy in Numbers 24, Josephus describes Israel as the most virtuous people on earth, thereby suggesting that genealogy is not the only criterion relevant to defining God's people: virtue plays a role too. ${ }^{4}$

Beyond the question of the meanings of genos and ethnos in Josephus' work, Gruen's conclusion that birth or ties of blood were not essential to Josephus' notion of the people of Israel is corroborated by the fact that for Josephus, non-Jews - that is, people with a nonIsraelite lineage - could become Jews by adopting the Jewish laws and way of life (including circumcision for men). ${ }^{5}$ This position meant that the proselyte's choice to live according to Jewish laws, seen as a virtuous decision, represented the decisive factor in the definition of membership in Israel. As a consequence, the importance of birth and lineage was to some extent relativized.

On the other hand, however, Josephus was proud of his priestly pedigree, which he repeatedly emphasizes in his work (Vita 1-6; C. Ap. 1.54). Moreover, he boasted of his alleged

\footnotetext{
${ }^{1}$ Gruen, "Josephus and Jewish Ethnicity," in Sibyls, Scriptures, and Scrolls: John Collins at Seventy, ed. Joel Baden et al. (Leiden: Brill, 2017), 489-508. See also Shaye J. D. Cohen, "IOY $\triangle \mathrm{AIO} \Sigma$ TO $\Gamma E N O \Sigma$ and Related Expressions in Josephus," in Josephus and the History of the Greco-Roman Period, ed. Fausto Parente (Leiden: Brill, 1994), 23-38.

${ }^{2}$ Gruen, "Josephus and Jewish Ethnicity," 491, referring to A.J. 1.192, 1.234-235, 4.115-116, 5.97, 5.113, 12.226.

${ }^{3}$ Gruen, "Josephus and Jewish Ethnicity," esp. 494, 496; quotation at 503.

${ }^{4}$ Gruen, "Josephus and Jewish Ethnicity," 493, referring to A.J. 4.114-115. See also A.J. 4.2, where the Israelites state that God helps them because of two factors: their ancestors and their own virtue. In this case, however, the statement proves wrong, as they are sinning against God.

5 Daniel Schwartz contends that from Josephus' perspective, only non-Jewish men could become Jews, by undergoing circumcision, that is, a bodily change. Schwartz notes that nowhere in his work does Josephus speak of a non-Jewish woman becoming Jewish. Josephus rather describes her as adopting Jewish practices (Schwartz, "Doing like Jews or Becoming a Jew? Josephus on Women Converts to Judaism," in Jewish Identity in the GrecoRoman World, ed. Jörg Frey, Daniel R. Schwartz, and Stephanie Gripentrog [Leiden: Brill, 2007], 93-109). If Schwartz is right, Josephus' approach could be seen as a continuation of the view reflected in several biblical texts, that women who marry Israelites are expected to adopt their husbands' deity and religious customs (without any formal rite of "conversion"). The difference, however, is that Josephus occasionally refers to women who have adopted a Jewish lifestyle without being married to a Jew (as in the case of queen Helena of Adiabene).
} 
genealogical connection with the Hasmonean dynasty. The aristocratic, priestly outlook, with its heavy emphasis on lineage, thus remained an integral part of Josephus' worldview. ${ }^{6}$

How do these two dimensions of Josephus' thought hang together? Is the difference of emphasis to be explained by the fact that we are dealing with the definition of Israel in the one case and the definition of an individual's pedigree in the other? Or is there a tension in Josephus' thought concerning the role played by genealogy and virtues in the cases of both the nation and the individual?

In this paper, I will distinguish between Josephus' thoughts about individual pedigree on the one hand and those about the role played by genealogy in the definition of the people of Israel (focusing on the integration of converts) on the other. My aims are first to analyze how Josephus ranked and articulated lineage and virtue (including the willingness to follow a certain lifestyle) and second to assess the respective roles that his priestly education and his Roman context played in the way(s) he reflected on these issues.

\section{Individual lineage: Josephus' priestly and aristocratic outlook}

\subsection{Josephus' ancestry}

As numerous scholars have emphasized, Josephus claimed a prestigious pedigree in two respects, asserting at the beginning of his autobiography that he was of both priestly stock and Hasmonean - that is, royal-lineage. ${ }^{7}$ On the whole, however, he emphasizes his priestly origins much more than his Hasmonean ones, which in fact were both royal and priestly, as A.J. 16.187 makes clear - this passage associates Josephus' Hasmonean origins of with "priestly

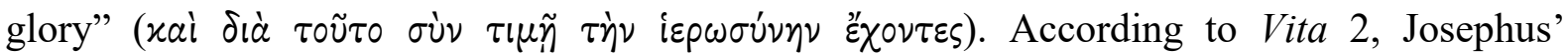
connection with the Hasmoneans was through his mother, yet priestly status was not transmitted through the mother. Since Josephus was himself a priest, he must have had a priestly background on his paternal side too. ${ }^{8}$ Mentioning a mother's prestigious origins was uncommon in ancient Jewish literature but made sense in a Greco-Roman context. ${ }^{9}$ This reference was meant to highlight Josephus' status in the eyes of non-Jewish readers in Rome.

\footnotetext{
6 Steve Mason argues that Josephus never embraced a Pharisaic perspective, and remained an aristocratic priest throughout his life (Mason, Flavius Josephus on the Pharisees: A Composition-Critical Study [Leiden: Brill, 1991], 325-56, 374).

7 Vita 1-7; see also A.J. 16.187. Martin Goodman thus writes: “Josephus' self-description in his autobiography neatly encapsulates the two very different lineages that brought high status in Jewish society. He could boast an impressive ancestry both priestly and royal" (Goodman, Rome and Jerusalem: The Clash of Ancient Civilizations [New York: Alfred A. Knopf, 2007], 335).

${ }^{8}$ See the discussion in Steve Mason, Life of Josephus: Translation and Commentary (Leiden: Brill, 2001), 5-6, n. 13.

${ }^{9}$ According to Pnina Stern, "The reason for Josephus' mention of his mother can be found in Roman culture, in which the mother's origins and her ancestry are cited with respect" (Stern, "Life of Josephus: The Autobiography of Flavius Josephus," JSJ 41 [2010]: 63-93, 71-72). She mentions Suetonius, Iul. 6 as a parallel to Vita 2. As a
} 
At the beginning of his autobiography, Josephus also states that his family belonged to the first of the twenty-four priestly classes (Vita 2). What he writes in the Vita as well as in Against Apion about the care with which priestly genealogies and marriages were catalogued, suggesting that these records were kept in public archives, is meant to enhance the validity of this claim (Vita 6; C. Ap. 1.30-36).

\subsection{Judean and Roman elites}

As Michael Tuval has noted, Josephus' insistence on his priestly lineage has everything to do with the status of priests in Jewish society, not only in Judea but also in the Diaspora, where there is evidence that priests were granted a special role in synagogal contexts, in certain places at least. ${ }^{10}$ In Vita 1, Josephus states: "Different [peoples] base their claim to nobility (eugeneia) on various grounds; with us a connexion with the priesthood is the hallmark of an illustrious ancestry (genous lamprotēs, lit. 'brilliance of birth')" (trans. H. St. J. Thackeray, LCL, 3, slightly modified). Hence, to quote Tuval, "Josephus equated Jewish priesthood with Jewish nobility." 11

Tuval further posits that Josephus insisted upon his priestly origins because he was very much aware of the status of priests within Roman society. Although Roman priesthoods were not hereditary privileges as in a Jewish context - one was not born a Roman priest - they nevertheless represented prestigious functions intimately associated with elite status and the nobility. ${ }^{12}$ G. J. Szemler notes that from the beginning of the third century BCE to the time of Julius Caesar, only one novus homo, or "new man" (a plebeian who was elected consul), served as pontifex maximus, and only two novi homines reached the augurate. ${ }^{13}$ The correlation between patrician status and priesthoods was thus very strong. ${ }^{14}$ Even at the end of the first century CE, some priestly or religious functions were still associated with patricians. ${ }^{15}$

matter of fact, the importance of maternal lineage was even stronger in a Greek context than in a Roman one. See Christophe Badel, La noblesse de l'empire romain: Les masques et la vertu (Seyssel: Champ Vallon, 2005), 31516.

10 Tuval, From Jerusalem Priest to Roman Jew (Tübingen: Mohr Siebeck, 2013), 260-74.

11 Ibid., 274. Christophe Badel posits that Josephus defined Jewish nobility in accordance with the Roman model, because he understands Josephus' statement in Vita 1 as associating nobility with a given function (priesthood), just as in Rome the consulship conferred nobility on those who assumed it and on their descendants (La noblesse de l'empire romain, 314). The fundamental difference that Badel overlooks, however, is that a Jewish priest was born a priest rather than elected to this function. The similarity is thus superficial and misleading, because Jewish priesthood was exclusively a matter of genealogy. It is nevertheless possible that Greeks and Romans who were not well informed could read the beginning of Josephus' Vita the way Badel does.

12 See G. J. Szemler, "Priesthoods and Priestly Careers in Ancient Rome," in Aufstieg und Niedergang der römischen Welt II.16.3, ed. Wolfgang Haase (Berlin: Walter de Gruyter, 1986), 2314-332, 2330.

13 Ibid., 2316-17.

${ }^{14}$ See Mason, Life of Josephus, 4, n. 4, referring to Polybius 6.56 and Cicero, Leg. 2.12.31, Resp. 2.12-14, and Dom. 1.1.

15 Goodman, Rome and Jerusalem, 334. 
Josephus' emphasis on his priestly pedigree was thus certainly meant to enhance his status in his Roman context.

The fact that Josephus equated Jewish nobility with Jewish priesthood means that from his perspective, genealogy essentially defined the true Judean nobility. ${ }^{16}$ Insofar as, in a Jewish context, a person could not be adopted by a priestly family (because adoption does not exist in Jewish law), a priest could only be born into the priesthood, as the son of a priest. ${ }^{17}$ In Roman society, by contrast, although nobility (nobilitas) had a lot to do with one's birth into a prestigious family, non-patricians who were elected to the consulship had the privilege of conferring nobility upon their descendants. Moreover, from the end of the first century BCE onward, patrician status could be conferred on individuals as a reward for special services. ${ }^{18}$ In addition, a patrician could adopt a plebeian son (and vice versa: at the time of the Republic, a patrician who wanted to run for tribune of the plebs could organize his adoption by a plebeian for electoral purposes, although this was unusual). ${ }^{19}$ Social mobility was thus less strictly limited by genealogical considerations in Roman society than in the Judean one, even though the ancient patrician families boasted of their illustrious ancestors and tried to use them as political assets. ${ }^{20}$

Yet beyond these differences, Josephus displays a keen sense of the common interests of the Judean and the Roman elites, which resulted in a partly shared worldview (from Josephus' perspective). Hence he repeatedly depicts the Judean aristocracy, both before and during the war, as ready to reach a compromise with the Roman authorities. ${ }^{21}$ This is not really surprising: the wealthy classes were also those who had the most to lose in a war. Moreover, Josephus presents the nobility in Jerusalem as preferred targets of the rebels, whom he repeatedly calls

\footnotetext{
${ }^{16}$ In theory, another source of nobility could lie in the Davidic royal line, but Josephus' writings do not reflect a valorization of the Davidic pedigree. Cf. Psalms of Solomon 17, which criticizes the Hasmoneans and expects a Davidic messiah.

${ }^{17}$ On adoption in biblical narratives and law, see Marcel-Henri Prévost, "Remarques sur l'adoption dans la Bible," Revue internationale des droits de l'antiquité 14 (1967): 67-77; Shalom M. Paul, "Adoption Formulae: A Study of Cuneiform and Biblical Legal Clauses," Maarav 2.2 (1979-80): 173-85; Lucien-Jean Bord, "L'adoption dans la Bible et dans le droit cunéiforme," Zeitschrift für Altorientalische und Biblische Rechtsgeschichte 3 (1997): 174-94; Ofir Yarden, "Adoption in Judaism," Dialog: A Journal of Theology 51.4 (2012): 276-83.

18 See Goodman, Rome and Jerusalem, 334: "During most of the Republican period, patrician status was defined by descent alone, but from the time of Julius Caesar onwards, and under the emperors, the status might also be conferred on favoured individuals as a privilege. By this time, however, the status meant little, since by the end of the Republic, the distinction between patricians and plebeians had lost almost all political and social significance: rich plebeians had long exercised political power as magistrates, and plebeian and patrician families had long intermarried."

${ }^{19}$ Philippe Moreau, "Les adoptions romaines," Droit et cultures 23 (1992): 13-35, 20.

${ }^{20}$ Badel, La noblesse de l'empire romain, 106-55; Gary D. Farney, Ethnic Identity and Aristocratic Competition in Republican Rome (New York: Cambridge University Press, 2007) (which focuses on the ethnic origins of the most important families); Olivier Hekster, Emperors and Ancestors: Roman Rulers and the Constraints of Tradition (Oxford: OUP, 2015), 12-17.

${ }^{21}$ See, for example, B.J. 6.114 .
} 
"tyrants." 22 Similarly, he describes the Roman emperors who behaved in a tyrannical way as oppressing the nobility within Roman society. ${ }^{23}$ Josephus thus writes about Caligula:

Rome above all felt the horror of his actions, since he gave it no more privilege than other cities, but harried the citizens, especially the senators and those who were of the patrician class or had special honours because of distinguished ancestors ( $\propto$ ai $\mu \alpha \dot{\lambda} 1 \sigma \tau \alpha \tau \dot{\eta} \nu \sigma u ́ \gamma \varkappa \lambda \eta \tau \sigma \nu$

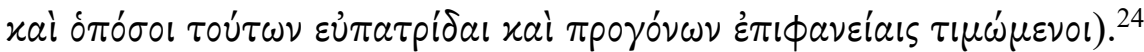

Here Josephus' testimony echoes that of Suetonius (Calig. 35) and other Roman authors who were part of the elite. ${ }^{25}$

In Josephus' work, the word eupatridēs designates Roman patricians not only in A.J. 19.2 but also in nearly all the other passages where the term appears. ${ }^{26}$ It is probably not by chance that the only place where he employs eupatrides in connection with the Judean elite presents Herod as a tyrant oppressing the Judean nobility (A.J. 17.307). ${ }^{27}$ Herod is here retrospectively cast in the role of Caligula, the paradigm of the bad Roman emperor, while the Judean aristocracy is referred to by a term that means "patrician" elsewhere in Josephus' writings. From Josephus' perspective, the Judean and Roman elites had a lot in common, including similar problems.

Josephus' writings therefore reflect what could anachronistically be called a class perspective. Moreover, the way he speaks about both the Judean and the Roman aristocracies reveals his acculturation to the Weltanschauung of the nobility that he came to know in Rome. ${ }^{28}$ Josephus' emphasis on the importance of education and virtue in the definition of the true nobility further corroborates this point.

\subsection{Pedigree and virtue}

In Greek, the link between birth and nobility (eugeneia) seems straightforward, yet the latter's definition is more complex than one might think at first glance. For many Greek and Roman authors, nobility (eugeneia, nobilitas) had a moral dimension as well. As Christophe Badel emphasizes, in Rome the origin of a family's nobilitas always had to do with the achievements

${ }^{22}$ B.J. 1.10-11, 1.24, 1.27-28, 2.442, 2.447, 2.564, 4.151, etc.

${ }^{23}$ A.J. 18.226 (Tiberius), 19.2-3 (Caligula), etc. In B.J. 2.213, Agrippa is said to have prevented Claudius from harming the patricians.

${ }^{24}$ A.J. 19.2, trans. Thackeray, LCL, 215.

25 See also Philo, Legat. 342.

${ }^{26}$ This term is quasi-exclusively associated with a Roman context. See B.J. 2.212-13; A.J. 18.226, 19.2, 19.75, $19.132,19.136$.

27 The context is a Jewish embassy to Rome, whose delegates complained about Herod (A.J. 17.304-11).

28 Stern, "Life of Josephus," 77. On Josephus' connections in Rome, see, e.g., Hannah M. Cotton and Werner Eck, “Josephus' Roman Audience: Josephus and the Roman Elites," in Flavius Josephus and Flavian Rome, ed. Jonathan Edmondson, Steve Mason, and James Rives (Oxford: OUP, 2005), 37-52. 
and the virtus of illustrious ancestors, and their descendants had to be worthy of them. ${ }^{29}$ Moreover, numerous philosophers - starting with Plato - defined true nobility in relation to virtue rather than to family origins. ${ }^{30}$

Philo's discussion of eugeneia illustrates this philosophical trend. In his treatise On the Virtues, we encounter a radical opposition between social and moral eugeneia:

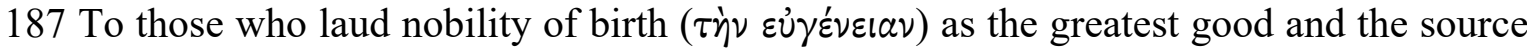
of other great goods let no mild reproach be spoken, since they above all imagine those of ancient wealth and renown to be noble [...]. 189 Therefore, since nobility is the proper inheritance of a mind that has been purified by perfect purifications, one must call only the

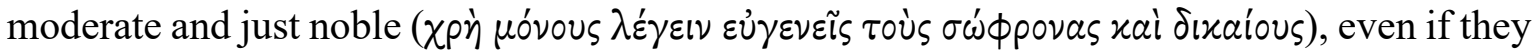
happen to have been born from household slaves or from those bought with money. But to wicked offspring who have sprung from good parents let the estate of nobility be closed off. $^{31}$

Philo's discourse has Stoic overtones and is comparable to that of Seneca, who writes in one of his letters to Lucilius: "Then who is well-born? He who is by nature well fitted for virtue. [...] No past life has been lived to lend us glory, and that which has existed before us is not ours; the soul alone renders us noble (animus facit nobilem), and it may rise superior to Fortune out of any earlier condition, no matter what that condition has been." 32 In this same passage ( $\$ 5)$, Seneca derides the ancestral imagines that noble families in Rome proudly exhibited, arguing that virtue, which is the main criterion of nobility, cannot be inherited. ${ }^{33}$

Contrary to Philo and Seneca, Josephus does not adopt a philosophical approach to nobility and never minimizes the importance of having been born into a socially prominent family. However, lineage is not the only criterion that defines the elite in Josephus' eyes. First, he repeatedly claims that his priestly origins led him to be trained in the holy books of the Jews from early childhood on (a point that enhances his legitimacy as a historian of his people). ${ }^{34}$ This connection between birth and knowledge illustrates a notion often found under Josephus' pen: people who are well-born should display intellectual (as well as moral) virtues. Josephus

\footnotetext{
${ }^{29}$ Badel, La noblesse de l'empire romain, 156-86, 319-24. Cf. Philo, Ios. 172, where Jacob's sons state that "almost alone among men we owe our title of nobly-born to the surpassing virtues of father, grandfather, and

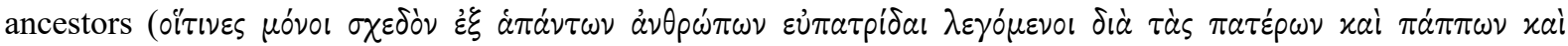

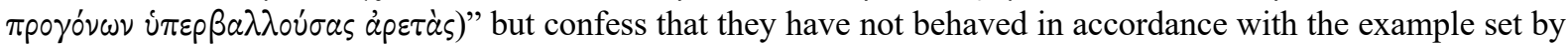
their illustrious predecessors (trans. F. H. Colson, LCL, 225).

${ }^{30}$ Badel, La noblesse de l'empire romain, 320-21.

31 Virt. 187-189, trans. Walter T. Wilson, Philo of Alexandria, On Virtues: Introduction, Translation, and Commentary (Leiden: Brill, 2011), 83. In Deus 150, noble birth is also considered an earthly good, cherished by the masses, which one must be able to disregard in order to look for superior, divine goods.

${ }^{32}$ Epist. 44.5, trans. Richard M. Gummere, LCL, 289.

${ }^{33}$ On this text, see Badel, La noblesse de l'empire romain, 322-23.

${ }^{34}$ See A.J. 16.187; Vita 8; C. Ap. 1.54. See also Tuval, From Jerusalem Priest to Roman Jew, 260. In C. Ap. 1.54, the expression hiereus ek genous does not mean that Josephus was born a priest but did not perform the role of a priest (on this interpretation of hiereus to genos, see Daniel R. Schwartz, "Priesthood and Priestly Descent: Josephus, Ant. 10.80," JTS 32 [1981]: 129-35). Rather, it means that he received special training because he was the son of a priest.
} 
is clearly aware that this is not always the case and that some members of the nobility are unworthy, yet the association between noble birth and intellectual qualities may be considered a Josephan ideal.

After intellectual abilities, virtue is the second criterion of true nobility. This association is manifest in several passages of Josephus' work, such as Vita 7, in which he emphasizes that his father was prominent because of both his eugeneia and his righteousness (dikaiosynēe). Similarly, Vita 427 presents Josephus' Cretan wife as having been born "of parents who were

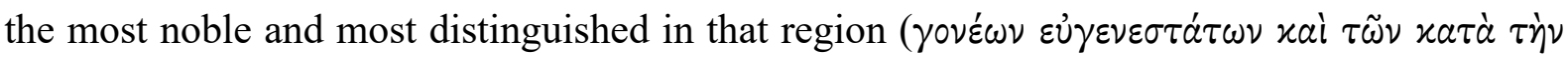

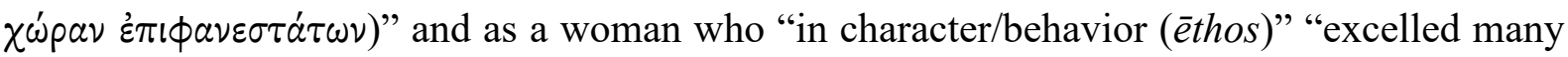
women." 35 Josephus describes other contemporaries as both being of noble extraction and characterized by virtue. The high priest Ananus, for instance, who was originally one of the leaders of the war but remained a moderate and was later murdered by the Zealots, is represented as a man of noble birth (eugeneia) who was also extremely righteous (dikaiotatos) (B.J. 4.319). The association between noble birth (i.e., prestigious ancestors) and virtue is found in the context of Josephus' retelling of biblical stories as well. Abraham's servant thus praises Rebecca for both her eugeneia and her generosity (chrēstotēs) (A.J. 1.247). ${ }^{36}$ These passages show that Josephus partook of an ideal of nobility associating noble birth and virtue that was widely shared in the Greco-Roman world.

In some cases, this association between nobility and virtue even leads to an allegorical or purely ethical understanding of eugeneia. ${ }^{37}$ Whereas Josephus generally uses eugeneia or eugenēs to speak about a person of royal or priestly lineage, in a few cases he also employs these terms in a metaphorical or moral way to designate someone with a noble soul - this is especially true when eugenès characterizes psyche, as A.J. 12.255, for example, demonstrates. Does this imply that nobility (in the sense of social status, not the quality of the soul) can be disconnected from genealogy? Can virtue compensate for humble origins?

For Cicero, the answer was positive. In his speech For Sestius, he addressed the Roman youth in these terms:

You, young Romans, who are nobles by birth, I will rouse to imitate the example of your ancestors; and you who can win nobility by your talents and virtue (ingenio ac virtute), I will exhort to follow that career in which many 'new men' have covered themselves with honour and glory. ${ }^{38}$

\footnotetext{
${ }^{35}$ Trans. Mason, Life of Josephus, 170.

${ }^{36}$ See also A.J. 7.315, concerning Benaiah ( $1 \mathrm{Chr} 27: 5$ ), who is characterized by his priestly lineage and his virtue, aretē.

${ }^{37}$ In C. Ap. 1.220, Josephus thus speaks of the eugeneia of certain cities and nations - their "nobility," or illustrious reputation - which some people slander. But as John Barclay notes, in the following paragraphs Josephus provides examples exclusively of cities (Flavius Josephus: Against Apion [Leiden: Brill, 2007], 128, n. 756). The only nation that he has in mind is in fact the Jewish people (see also B.J. 4.181, for the eugeneia of Jerusalem). In B.J., however, Josephus has Agrippa II mention the nobility (eugeneia) of the Greeks (2.365).

${ }^{38}$ Pro Sestio 65.136, trans. R. Gardner, LCL, 223.
} 
Cicero refers to the fact that by serving as consuls, men who were not originally members of the nobilitas could confer nobility on their descendants. He makes clear that nobility is either granted at birth, by the fact of being born into one of Rome's patrician families, or acquired through talent and virtue. At the same time, he also reminds those who are noble by birth that they must prove worthy of their origins and thus themselves display virtue.

While Josephus certainly would have concurred with the latter exhortation, he could not assert that it was possible for virtuous men of humble origins to access the true Jewish nobility - namely, the priesthood. The genealogical principle stood firm for him. It seems, however, that virtue, understood as the will to live according to the Jewish laws, could compensate for the non-Israelite pedigree of a convert. Let us now examine the respective roles of lineage and virtue in Josephus' view of the people of Israel and the converts who join them.

\section{Josephus" "open" notion of peoplehood and Roman citizenship grants}

In Josephus' writings, the importance of noble birth or ancestry - eugeneia - is found mainly in passages dealing with his own lineage, with those of other Judean priests or elite members of Judean society more broadly (such as Mariamne, Herod's wife), or with members of the Roman nobility. ${ }^{39}$ To what extent did he also conceive of Israel as a people defined by ancestry and lineage ${ }^{40}$ (We must keep in mind that in the Bible, priests, Levites, and Israelites are all defined by birth; moreover, strictly genealogical definitions of the people of Israel had existed in the past-as Ezra, Jubilees, and other works show—and continued to exist in Josephus' time. ${ }^{41}$ )

The notion of Israel as a group sharing common ancestors is indeed present in Josephus' work. ${ }^{42}$ For example, he explains the obligation to leave some of the fruit in the field for the

39 See, for example, B.J. 1.435, 449, 458, 468, 476, 522; 2.311 (Berenice); 4.319, 357 (the nobility in Jerusalem as a target of the rebels' hostility); A.J. 4.26 (Moses and Aaron's noble family origins); 10.59, 186; 15.14 (John Hyrcanus), 73, 210 (Mariamne), 236 (eadem); 16.192 (Mariamne's sons); Vita 1 (Josephus' father). For members of the Roman elite, see B.J. 2.184, 2.250, 4.647. In addition to eugenia or eugenés, Josephus uses the word eupatridēs to speak about the Roman nobility (see n. 27 above).

40 See n. 38 above for examples in Josephus' work of eugeneia as characterizing a collective and even the city of Jerusalem.

${ }^{41}$ On these genealogical definitions of Israel and the resistance of some groups to the integration of non-Jews within the people, see, e.g., Gary G. Porton, The Stranger within Your Gates (Chicago: University of Chicago Press, 1994); Christine E. Hayes, Gentile Impurities and Jewish Identities: Intermarriage and Conversion from the Bible to the Talmud (Oxford: OUP, 2002); Martha Himmelfarb, A Kingdom of Priests: Ancestry and Merit in Ancient Judaism (Philadelphia: University of Pennsylvania Press, 2006); Matthew Thiessen, Contesting Conversion: Genealogy, Circumcision, and Identity in Ancient Judaism and Christianity (Oxford: Oxford University Press, 2011).

42 See, e.g., B.J. 5.379, 6.107; A.J. 4.236, 5.97; John M. G. Barclay, "Constructing Judean Identity after 70 CE: A Study of Josephus's Against Apion," in Identity and Interaction in the Ancient Mediterranean: Jews, Christians and Others-Essays in Honour of Stephen G. Wilson, ed. Zeba A. Crook and Philip A. Harland (Sheffield: Sheffield Phoenix Press, 2007), 99-112, 102; Philip F. Esler, "Judean Ethnic Identity in Josephus' Against Apion," in A Wandering Galilean: Essays in Honour of Seán Freyne, ed. Zuleika Rodgers et al. (Leiden: Brill, 2009), 7391, 81 . 
poor as grounded in the kinship (syngeneia) existing among Israelites (A.J. 4.236). ${ }^{43}$ However, as stated in the introduction, Josephus accepted the idea that proselytes could join the people of Israel; he thus had an open definition of the latter. That being so, were his criteria for membership within the people of Israel different from those related to membership in the priesthood? Or did he view converts as second-rank members of the people of Israel because of their lineage, just as gerim were ranked fourth (after priests, Levites, and Israelites) in the community of the Damascus Document ${ }^{44}$

\subsection{Converts and lineage}

Some of Josephus' most important statements about converts are found in Against Apion, even though he addresses this issue only indirectly. Against Apion is a work in which Josephus attempts to defend the Jews against various slanderous charges, including the accusation of misanthropy. ${ }^{45}$ Within the framework of his description of the Jewish laws, Josephus therefore explains what the legislator, Moses, prescribed concerning those of foreign stock, in order to demonstrate that this legislation is not misanthropic and actually allows Jews to welcome foreigners into their midst:

209 The consideration that our legislator gave to the kindness to be shown to foreigners ( $\pi$ pos $\dot{\alpha} \lambda \lambda \circ \phi \cup$ u $0 \cup \varsigma$ ) is also worth noting. For he may be seen to have made the very best provision that we should neither corrupt our own habits ( $\tau \dot{\alpha}$ oix $x \tilde{\imath} \alpha$ ) nor begrudge those who choose to

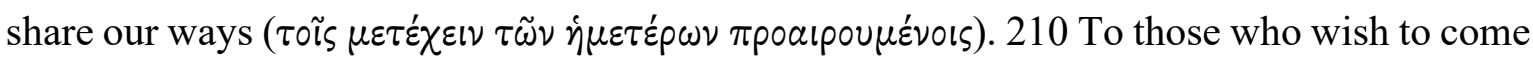

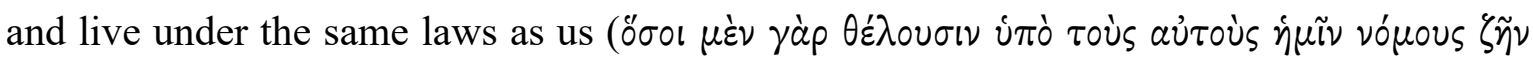
$\left.\dot{v} \pi \varepsilon \lambda \theta \sigma^{\prime} \nu \tau \varepsilon \varsigma\right)$ he gives a friendly welcome, reckoning that affinity is not only a matter of birth

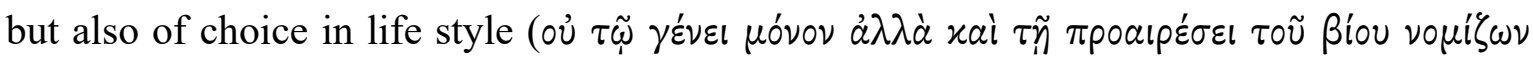

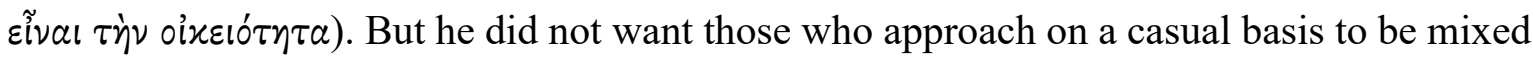
with our intimate ways. ${ }^{46}$

Although Josephus does not use the word "proselyte" (proselytos or other terms such as epélytos), it is clear that he is speaking here about people who convert to Judaism-meaning: who choose to live according to the Mosaic laws - and thus join the Judean ethnos. These people are described as allophyloi, "foreigners," based on both their descent and their original lifestyle. What enables them to join the people of Israel is their willingness to live under Jewish

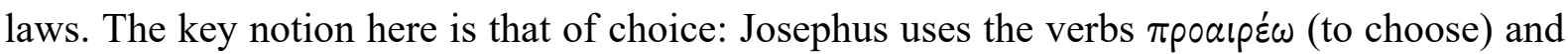

\footnotetext{
${ }^{43}$ See also A.J. 5.142, 18.359; Gruen, "Josephus and Jewish Ethnicity," 506.

${ }^{44}$ See CD XIV 3-6 and 4Q267 frag. 9 v 8-10; Katell Berthelot, "La notion de גר dans les textes de Qumrân," RevQ 19/74 (1999): 171-216, 186-93; Carmen Palmer, Converts in the Dead Sea Scrolls: The Gēr and Mutable Ethnicity (Leiden: Brill, 2017), 62-63, 99-102.

45 For a detailed analysis of Josephus' apologetic strategy, see Katell Berthelot, Philanthrôpia judaica: Le débat autour de la "misanthropie" des lois juives dans l'Antiquité (Leiden: Brill, 2003), 349-81, and Barclay's commentary in Flavius Josephus: Against Apion.

${ }^{46}$ C. Ap. 2.209-210, trans. Barclay, Flavius Josephus, Against Apion, 290-92. Cf. Philo, Abr. 251.
} 


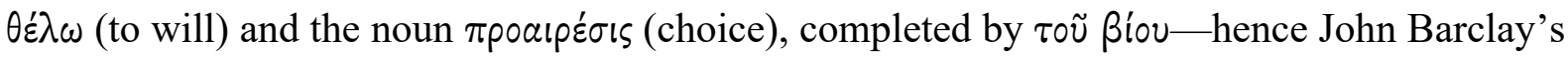
translation, "choice in life style." Most important, Josephus writes that Moses "reckon[ed] that

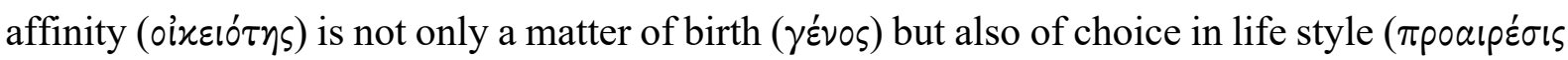

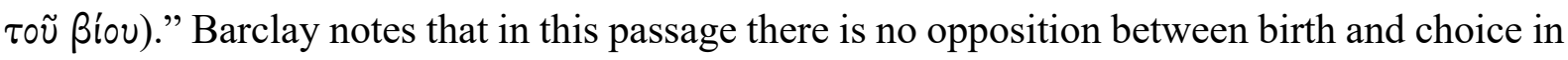
lifestyle, that "choice is an aspect of affinity supplementary to birth, not its antithesis," and thus concludes that this text cannot be used to demonstrate a shift from "ethnic tradition" to "religion." 47 Barclay is right to emphasize that there is no opposition between genos and proairesis, yet the fact remains that Josephus is here describing two ways to establish oikeiotēs. One way is to be a native Jew, and another way is to choose to live according to Jewish laws despite not being a Jew by birth (which comes close to the modern notion of conversion). These two are not opposed but are nevertheless distinct. Josephus is not claiming that in order to be a Jew, one needs to combine both genos and proairesis. (I am not aware of a single passage in his work where he states that a Jew who chooses not to live according to Jewish laws ceases to be a Jew, which would imply that proairesis is a necessary condition that must be added to birth.)

Barclay translates oikeiotēs as "affinity," which is clearly a possibility but leaves aside the notion of kinship. Yet as he himself notes, this term "evokes a close relationship (cf. 'our own habits,' $\tau \dot{\alpha}$ oixعĩ $\alpha$, in 2.209), and normally relates to the household or members of the wider family (e.g., Philo, Mos. 1.241, 324; 2.176, 278)." "48 Indeed, oikeiotēs can be used as a synonym of syngeneia and may therefore be translated as "kinship" in some cases (I would favor this translation here). ${ }^{49}$ However, instead of implying common ancestors or referring to birth, as syngeneia does, the term oikeiotēs, which is based on oikos ("house" or "household"), corresponds to the quality of that which is "at home," appropriate, or fitting. Hence, it reflects a slightly different notion of kinship, one that is in harmony with the metaphor of citizenship that underlies Josephus' text (on this metaphor, see below). The idea that a relation of oikeiotess may exist not only between people of the same genos but also between fellow citizens who are not directly related by blood can be found, for example, under the pen of the Stoic philosopher Arius Didymus, in his presentation of Peripatetic philosophy. ${ }^{50}$ Similarly, in Against Apion, proselytes are considered to enter into a kinship (oikeiotess) with native Israelites, but this

\footnotetext{
${ }^{47}$ Barclay, Flavius Josephus, Against Apion, 291-92, n. 847 (italics in the original), responding to Shaye J. D. Cohen, The Beginnings of Jewishness: Boundaries, Varieties, Uncertainties (Berkeley: University of California Press, 1999), 69-139.

${ }^{48}$ Barclay, Flavius Josephus, Against Apion, 291, n. 847.

${ }^{49}$ See, for example, the quotation of Theophrastus in Porphyry's De abstinentia 3.25 .2 (in which the adjectival forms are used), and Philo, Confus. 150, Prob. 79. In Josephus' work, oikeiotēs and syngeneia are sometimes synonymous and interchangeable; see Gruen, "Josephus and Jewish Ethnicity," 506.

${ }_{50}$ His work is quoted in Stobaeus' Anthology. See Curt Wachsmuth, ed., Ioannis Stobaei: Anthologii (Eclogae physicae et ethicae) (Berlin: Weidmann, 1884), 2:116-28, 120, lines 8-14. Arius Didymus also writes that there is a form of oikeiotês among human beings in general. On the attribution of this text to Arius, see Charles H. Kahn, "Arius as a Doxographer," in On Stoic and Peripatetic Ethics: The Work of Arius Didymus, ed. William W. Fortenbaugh (New Brunswick: Transaction Books, 1983), 3-13.
} 
kinship is not based on common ancestors; rather, it is based on a common lifestyle in accordance with the laws of Moses.

Josephus was probably inspired by Philo, who reflects at length on what constitutes the true kinship among the members of the people of Israel, to the point of contrasting kinship linked to common ancestors with the spiritual syngeneia or oikeiotēs based on wisdom and the search for the truth (i.e., God). ${ }^{51}$ According to Philo, when faithfulness to God and the covenant is at stake, the two kinships may even be vigorously opposed and the natural kinship put aside (see Mos. 2.171, Spec. 1.317, and Spec. 3.126 in particular). In Questions on Exodus 2.36, Philo comments upon Exodus 24:8b and "the blood of the covenant," understood as a symbol of kinship, as follows:

And the form of kinship is twofold: one is that among men, which has its origin in ancestors, while that among souls has its origin in wisdom. Now he (Moses) did not mention the kinship of ancestors and offspring, because it is also common to irrational animals, but from the other (kind of kinship) as from a root grew wisdom [probably to be corrected as: but the other (kind of kinship) grew from wisdom as from a root]..$^{52}$

More specifically, according to On the Special Laws 4.159 (related to Deuteronomy 17:15, which commands that Israel's king be chosen from among the Israelites), the true and superior kinship among the members of the people of Israel consists of having in common one politeia (citizenship/civic body) with the same law for all and "one God who has taken all members of the nation for His portion." ${ }^{53}$ For Philo, true kinship is thus based not on common ancestry but on a common political-legal-religious experience.

Also in the treatise On the Special Laws, Philo describes proselytes as having broken from their original families and exhorts native Israelites to welcome them as new family members:

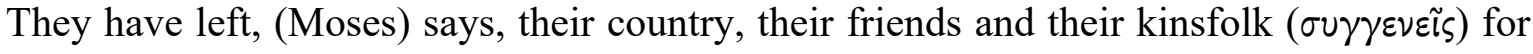

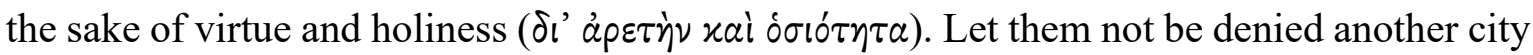

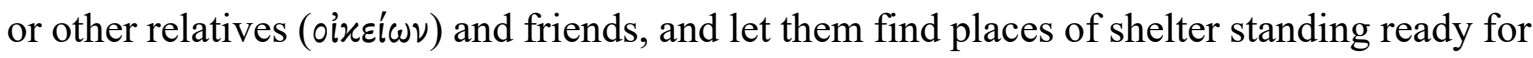
refugees to the camp of piety $[\ldots] .{ }^{54}$

Proselytes have abandoned their natural kinship ties with parents, brethren, etc. (syngeneis), and from Philo's perspective, they are to find new relatives (oikeioi) in Israel. His statement does not mean that they will be "adopted" by a particular Jewish family; rather, it is the Jewish people as a whole who become their adoptive family. ${ }^{55}$ Philo's use of the term oikeioi in this passage to refer to the proselytes' new kin recalls Against Apion 2.210. Once read in the light

\footnotetext{
51 On the different types of kinship in Philo's work, see Katell Berthelot, L' "humanité de l'autre homme” dans la pensée juive ancienne (Leiden: Brill, 2004), 119-48.

${ }^{52}$ Trans. Ralph Marcus, LCL, 77-78; see note a at 78.

53 Trans. F. H. Colson, LCL, 107.

${ }^{54}$ Spec. 1.52, trans. Colson, 129, slightly modified.

55 This perspective differs from Philo's characterization of the mixed multitude that left Egypt with Israel at the time of the Exodus. In Mos. 1.147 he presents them as "a bastard host, so to speak," in contrast to "the true-born" (native Israelites) (trans. F. H. Colson, LCL, 353). However, I do not consider this passage to reflect Philo's view of the proselytes who lived in his own time. Pace Cohen, The Beginnings of Jewishness, 161.
} 
of Philo's work, Josephus' choice of the word oikeiotess (rather than syngeneia) there to indicate a kinship between native Israelites and proselytes that does not rely on blood ties makes all the more sense.

Philo's emphasis in On the Special Laws 1.52 (quoted above) on the proselytes' search for virtue (aretē) and holiness (hosiotēs) shows that from his perspective, moral/religious qualities were as important for membership in Israel as genos, or lineage. Elsewhere in his work, he in fact states that the former is more central than the latter and defines Israel as the people who see God. ${ }^{56}$ He sharply criticizes native Jews who abandon the ancestral laws and do not remain faithful to the covenant; in contrast to proselytes, these Jews are not considered by Philo to be true members of the people of Israel anymore.

Unlike Philo's belief that natural kinship may be (or become) irrelevant to the definition of Israel and that virtue and holiness have primacy, the passage of Against Apion examined above does not minimize the value of genos. For Josephus, both genos and proairesis, birth and choice (that is, conversion), constitute the foundations of oikeiotēs. He does not oppose these two ways of belonging to Israel, as Philo occasionally does, but rather sees them as complementary. All in all, Josephus never completely relativizes the importance of lineage. Are proselytes, then, to be considered second-rank members of the people of Israel because of their faulty ancestry?

\subsection{The metaphor of citizenship}

Elsewhere in Against Apion, Josephus echoes yet another Philonic argument, suggesting that proselytes become new citizens in the Mosaic civic body (politeia). ${ }^{57}$ Contrasting the Spartans' and Judeans' attitudes toward foreigners, he writes:

260 They [the Lacedaemonians] perhaps might reasonably be criticized for their

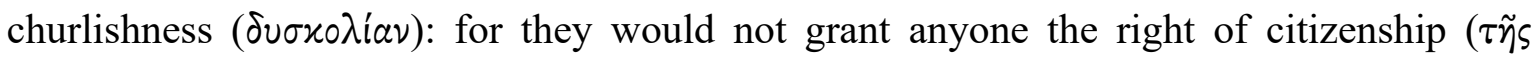

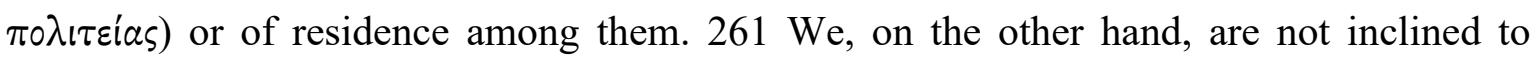
emulate other people's [customs/laws], but gladly welcome those who wish to share ours;

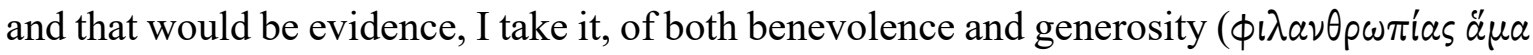

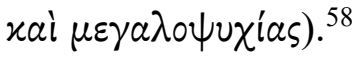

The possibility of integrating new members into the people of Israel, based on their acceptance of the Mosaic laws, is here implicitly connected to the notion of citizenship, which in the case of the Jewish people is metaphorical. Josephus characterizes the Lacedaemonians' reluctance to grant Spartan citizenship to foreigners as a mark of $d y s k o l i a$ or misanthropy. On the contrary,

\footnotetext{
${ }^{56}$ See, e.g., Post. 92, Fug. 208, Abr. 57, Praem. 44; Ellen Birnbaum, The Place of Judaism in Philo's Thought: Israel, Jews, and Proselytes (Atlanta: Scholars Press, 1996), Chap. Two (esp. 65, n. 12).

57 See Philo, Spec. 1.51-53; Virt. 108, in which Philo again addresses the issue of proselytes, describing them as those who want to become members of the "politeia of the Jews," an expression which makes the meaning of politeia as "community of citizens" even clearer. See also Virt. 179.

${ }^{58}$ C. Ap. 2.260-261, trans. Barclay, Flavius Josephus, Against Apion, 317-18.
} 
the Jews, who welcome strangers wishing to live according to Jewish laws, display philanthropia (generosity). This contrast implies that the integration of newcomers within the Jewish community is similar to a grant of citizenship.

As I have shown elsewhere, how Philo and Josephus employ the metaphor of citizenship to speak about the people of Israel has a lot to do with the Roman imperial context in which they lived. In particular, the argument that Moses' laws display philanthropia because they allow foreigners to become members of the Jewish people was strongly influenced by Roman and pro-Roman discourses celebrating the philanthrōpia of Rome in granting citizenship. ${ }^{59}$ The way that Josephus (following in Philo's footsteps) emphasized the openness of the Jewish "civic body" to newcomers who were not born into it may be considered a result of the impact that Roman notions and discourses had upon his worldview.

Furthermore, the citizenship metaphor has one crucial implication, especially if the model is that of Roman citizenship: the non-Israelite lineage of converts to Judaism ceases to be a problem, for new citizens do not need shared ancestors with those who were born citizens. What matters is the common acceptance of the law by all the members of the civic body, which is what creates the oikeiotēs. Josephus' use of the citizenship metaphor therefore suggests - at least in theory - that he perceived proselytes not as second-rank members of the people of Israel but as equal to the natives. At any rate, this is what he implies in Against Apion. His argument may have been merely apologetic and meant to align the Jews with the Romans. But it may also have genuinely reflected Josephus' notion of peoplehood after his years of immersion in Roman society.

\section{Conclusion}

In the first century CE, both acquiring Roman citizenship and joining the Roman nobilitas were theoretically possible for those who were not born with such status (but nobility was much harder to obtain than citizenship). By contrast, in Josephus' writings, insofar as nobility is equated with the priesthood, it is de facto restricted to those who are born into priestly families, while membership in the people of Israel is open. In both cases, however, birth and virtue matter. Ideally, true nobility goes along with certain behavior and moral standards, while membership in the people of Israel also implies virtue, as a consequence of one's obedience to God's law. Both statuses are related to birth, yet membership in the Jewish people may be disconnected from birth, in the case of converts. Therefore, the criteria of birth and virtue do

59 Berthelot, Philanthrôpia judaica, 272-79, 359-68, esp. 365-66; eadem, “Judaism as 'Citizenship' and the Question of the Impact of Rome," in In the Crucible of Empire: The Impact of Roman Citizenship upon Greeks, Jews and Christians, ed. Katell Berthelot and Jonathan J. Price (Leuven: Peeters, 2019), 107-29. On Philo, see also Caroline Carlier, La cité de Moïse: Le peuple juif chez Philon d'Alexandrie (Turnhout: Brepols, 2008), 171217. 
not carry the same weight in the case of Jewish nobility and that of Jewish "citizenship": in the former, noble birth (into a priestly family) is a mandatory and sufficient condition, for lack of virtue does not disqualify a priest from continuing to hold that status; in the latter, birth is a qualifying condition but not a mandatory one (since converts may join the people of Israel), while virtue, understood as the will to live according to the Jewish laws, is a mandatory condition only for those who are not born Jews (even though, from Josephus' perspective, it is expected of native Jews). A final point that needs emphasis is that in contrast to Philo, Josephus never claims that adherence to Jewish laws, truth, or God (i.e., virtue) represents a more fundamental aspect of membership in the people of Israel than birth.

As far as the respective roles of Josephus' priestly status and his Roman citizenship (or Roman context more broadly) are concerned, we may conclude on the one hand that his insistence on individual pedigree or lineage is clearly rooted in his Jewish culture, in which priestly origins were deeply valued and more irrevocably a matter of genealogy than those in a Roman context. Josephus nevertheless echoes Roman (or Greco-Roman) views on the importance of maternal ancestry and the complementary roles of lineage and virtue in the definition of nobility.

On the other hand, when membership in the people of Israel is at stake, Josephus is ready to use the metaphor of citizenship, as Philo had done before him, as well as a twofold definition of kinship (oikeiotēs) that allows participation in the ethnos on account of either birth/ancestry or the choice to live in accordance with the Jewish laws. In this case, it is clear that his position was influenced at least partly by Roman citizenship grants and the ideological discourses about Rome's "generosity" (philanthrōpia) in this practice. Yet Josephus does not minimize the criterion of birth for all that; rather, birth and conversion are two possible ways to become a member of the Jewish people, just as birth and a citizenship grant were two ways to become Roman. 